Article

\title{
Identification and Characterization of Type IV Pili as the Cellular Receptor of Broad Host Range Stenotrophomonas maltophilia Bacteriophages DLP1 and DLP2
}

\author{
Jaclyn G. McCutcheon, Danielle L. Peters and Jonathan J. Dennis * \\ CW405 Biological Sciences Building, 11455 Saskatchewan Dr. NW, Department of Biological Sciences, \\ University of Alberta, Edmonton, AB T6G 2E9, Canada; jgmccutc@ualberta.ca (J.G.M.); \\ dlpeters@ualberta.ca (D.L.P.) \\ * Correspondence: jon.dennis@ualberta.ca; Tel.: +1-780-492-2529
}

Received: 8 May 2018; Accepted: 15 June 2018; Published: 20 June 2018

\begin{abstract}
Bacteriophages DLP1 and DLP2 are capable of infecting both Stenotrophomonas maltophilia and Pseudomonas aeruginosa strains, two highly antibiotic resistant bacterial pathogens, which is unusual for phages that typically exhibit extremely limited host range. To explain their unusual cross-order infectivity and differences in host range, we have identified the type IV pilus as the primary receptor for attachment. Screening of a P. aeruginosa PA01 mutant library, a host that is susceptible to DLP1 but not DLP2, identified DLP1-resistant mutants with disruptions in pilus structural and regulatory components. Subsequent complementation of the disrupted pilin subunit genes in PA01 restored DLP1 infection. Clean deletion of the major pilin subunit, pilA, in S. maltophilia strains D1585 and 280 prevented phage binding and lysis by both DLP1 and DLP2, and complementation restored infection by both. Transmission electron microscopy shows a clear interaction between DLP1 and pili of both D1585 and PA01. These results support the identity of the type IV pilus as the receptor for DLP1 and DLP2 infection across their broad host ranges. This research further characterizes DLP1 and DLP2 as potential "anti-virulence" phage therapy candidates for the treatment of multidrug resistant bacteria from multiple genera.
\end{abstract}

Keywords: bacteriophage; phage; phage therapy; phage receptor; Stenotrophomonas maltophilia; Pseudomonas aeruginosa; Type IV pili; pilus

\section{Introduction}

The increasing antimicrobial resistance of bacterial infections in recent years is a global health concern, and is predicted to cause 10 million deaths annually worldwide surpassing those caused by cancer by 2050 [1], creating the possibility of a "post-antibiotic era" in the 21st century. One concern is the emerging pathogenic bacterium Stenotrophomonas maltophilia, which is rapidly increasing in prevalence in nosocomial and community-acquired infections [2-4]. This bacterium is ubiquitous in the environment and is easily transmitted between immuno-compromised patients and health care providers through direct contact and cough-generated aerosols [2,4]. Most commonly associated with respiratory infections, S. maltophilia can also cause severe bacteremia, meningitis, endocarditis, pneumonia and catheter-related bacteremia/septicemia. Once a S. maltophilia infection is established, treatment is difficult due to its innate resistance to a broad range of antibiotics including trimethoprim-sulfamethoxazole, $\beta$-lactams, macrolides, cephalosporins, fluoroquinolones, aminoglycosides, carbapenems, chloramphenicol, tetracyclines, and polymyxins [2,4]. S. maltophilia can also be found in polymicrobial infections with the opportunistic, multidrug resistant pathogen 
Pseudomonas aeruginosa [4]. P. aeruginosa is a major cause of nosocomial infections, particularly in immuno-compromised individuals such as AIDS, burn and cancer patients, and is the most prevalent pathogen found in the lungs of adult cystic fibrosis patients [5,6]. The inability to treat or control S. maltophilia and P. aeruginosa infections due to their intrinsic and adaptive multi-drug resistance and range of virulence factors, including type IV pili and biofilm formation [7], increases mortality and morbidity and exemplifies the need for alternative treatments to combat these antibiotic resistant bacteria.

The clinical application of bacteriophages to selectively kill target bacteria, known as phage therapy, shows promise as an alternative treatment of antibiotic resistant bacterial pathogens. Discovered a century ago, phages are ubiquitous viruses that exclusively attack and lyse specific target bacteria through adsorption to the host cell surface, multiplying exponentially as they kill bacteria [6]. Recent studies utilizing phage therapy in animal models [4-6,8-10] and human clinical trials [11-13] show the successful eradication of multidrug resistant bacterial infections by specific phage and demonstrate that phage therapy can be a successful treatment option in humans with no apparent side effects $[14,15]$. The specificity of phages for their hosts relies upon the presence of the correct surface receptor. Whereas spontaneous mutation of phage's cell surface receptors allows a bacterium to become resistant to phage infection, it can also attenuate the bacterium's fitness or pathogenicity if the phage targets a virulence factor, in what is termed an "anti-virulence strategy". Identifying bacterial receptors for phages such as the type IV pilus or lipopolysaccharide [16], and characterizing the mechanisms of phage-host interaction will enhance the development of phage cocktails targeting different receptors and creating evolutionary pressure towards bacterial avirulence.

While bacteriophages typically have a very narrow host range, recently discovered novel phages such as DLP1 and DLP2 are capable of infecting across taxonomic orders, using strains from both S. maltophilia and P. aeruginosa as hosts for propagation [17]. This unique ability suggests that DLP1 and DLP2 may be good candidate phages for use in phage therapy, as their unusually broad host ranges would minimize the number of different phages needed in one treatment. Extensive characterization of bacteriophages is essential before they can be used in clinical trials, for example, to ensure that they do not increase bacterial virulence through lysogenic conversion [18,19]. Therefore, the objective of the experiments presented in this paper is to understand the modes of infection of DLP1 and DLP2 across their broad host ranges. Herein, we identify the type IV pilus as the receptor for DLP1 and DLP2 infection of both S. maltophilia and P. aeruginosa strains. Identification of the mechanism of attachment for both phages has implications for their use as therapeutic agents and suggests that evolutionarily conserved bacterial specialized surface structures have been adopted by some phages as primary receptors for initial host cell interactions.

\section{Materials and Methods}

\subsection{Bacterial Strains, Phage and Growth Conditions}

Bacterial strains, bacteriophages and plasmids used in this study are listed in Table 1. The S. maltophilia strain D1585 was acquired from the Canadian Burkholderia cepacia complex Research and Referral Repository (Vancouver, BC) and S. maltophilia strain 280 was gifted from The Provincial Laboratory for Public Health-North (Microbiology), Alberta Health Services. The mini-Tn5-luxCDABE P. aeruginosa PA01 mutant library used for the receptor screen was a kind gift from S. Lewenza [20]. Additional PA01 mutants were obtained from the University of Washington $P$. aeruginosa transposon mutant library constructed with either an ISphoA/hah or ISlacZ/hah Tn5 IS50L derivative transposon [21,22]. P. aeruginosa and $S$. maltophilia strains were grown aerobically overnight at $30^{\circ} \mathrm{C}$ on half-strength Luria Bertani (1/2 LB) solid medium or in 1/2 LB broth with shaking at $225 \mathrm{rpm}$, and Escherichia coli strains were grown at $37^{\circ} \mathrm{C}$ in full LB, unless otherwise noted. Media was supplemented with antibiotics at the following final concentrations when necessary ( $\mu$ g per $\mathrm{mL}$ ): gentamicin $(\mathrm{Gm}), 10$ for E. coli and 35 for 
P. aeruginosa; chloramphenicol (Cm), 35 for E. coli and S. maltophilia D1585 and 75 for S. maltophilia 280; and tetracycline (Tc), 10 for E. coli, 50 for 280, and 100 for D1585.

Bacteriophages DLP1 and DLP2 were previously isolated on S. maltophilia strain D1585 and partially characterized, with the results subsequently reported [17]. DLP1 and DLP2 belong to the phage family Siphoviridae and are both capable of infecting across taxonomic orders, lysing different strains of S. maltophilia in addition to P. aeruginosa. Bacteriophage $\varphi \mathrm{KZ}$ belongs to the phage family Myoviridae and infects P. aeruginosa strains [23]. Propagation of DLP1, DLP2, and $\varphi$ KZ were performed using soft agar overlays as previously described [17]. Briefly, $100 \mu \mathrm{L}$ of culture was incubated with $100 \mu \mathrm{L}$ of phage for $20 \mathrm{~min}$, mixed with $3 \mathrm{~mL}$ of $0.7 \% 1 / 2 \mathrm{LB}$ top agar, and overlaid onto plates of $1 / 2 \mathrm{LB}$ solid media [24]. Plates were incubated at $30{ }^{\circ} \mathrm{C}$ overnight until plaques formed. Plates with confluent lysis were used to make high titer stocks by overlaying with $3 \mathrm{~mL}$ of modified suspension medium (SM) (50 mM Tris- $\left.\mathrm{HCl} \mathrm{pH} 7.5,100 \mathrm{mM} \mathrm{NaCl}, 10 \mathrm{mM} \mathrm{MgSO}_{4}\right)$, collecting the top agar and incubating for $30 \mathrm{~min}$ at room temperature on a platform rocker with $20 \mu \mathrm{L}$ chloroform per plate. The supernatant was collected after centrifugation for $5 \mathrm{~min}$ at $10,000 \times g$ and filter sterilized using a Millex-HA $0.45 \mu \mathrm{m}$ syringe-driven filter unit (Millipore, Billerica, MA, USA) and stored at $4{ }^{\circ} \mathrm{C}$. Titer of stocks was obtained using serial dilutions of phage stock into $\mathrm{SM}$ in the soft agar overlay technique with S. maltophilia D1585 for DLP1 and DLP2, and P. aeruginosa PA01 for $\varphi$ KZ.

Table 1. List of bacterial strains, phages and plasmids used in this study.

\begin{tabular}{|c|c|c|}
\hline Bacterial Strain & Genotype or Description & Source \\
\hline P. aeruginosa PA01 & Wildtype host for DLP1 & [25] \\
\hline S. maltophilia D1585 & Wildtype host for DLP1 and DLP2 & CBCCRRR * \\
\hline D1585 $\triangle$ pilA & Clean deletion of pilA in D1585 & This study \\
\hline S. maltophilia 280 & Wildtype host for DLP2 & PLPHN/AHS ** \\
\hline $280 \Delta$ pilA & Clean deletion of pilA in 280 & This study \\
\hline E. coli S17-1 & Conjugative donor strain & [26] \\
\hline E. coli $\mathrm{DH} 5 \alpha$ & Host for plasmid cloning & [27] \\
\hline \multicolumn{3}{|l|}{ Phage } \\
\hline DLP1 & Lytic phage & Accession: KR537872.1 [17] \\
\hline DLP2 & Lytic phage & Accession: KR537871.1 [17] \\
\hline$\varphi \mathrm{KZ}$ & Lytic Pseudomonas phage & Accession: NC_004629.1 [23,28] \\
\hline \multicolumn{3}{|l|}{ Plasmids } \\
\hline pBBR1MCS & Broad-host range cloning vector, $\mathrm{Cm}^{\mathrm{R}}$ & [29] \\
\hline pD1585pilA & pBBR1MCS carrying D1585 pilA, $\mathrm{Cm}^{\mathrm{R}}$ & This study \\
\hline pPA01pilA & pBBR1MCS carrying PA01 pilA, $\mathrm{Cm}^{\mathrm{R}}$ & This study \\
\hline p280pilA & pBBR1MCS carrying 280 pilA, $\mathrm{Gm}^{\mathrm{R}}$ & This study \\
\hline pD1585pilE & pBBR1MCS carrying D1585 pile, $\mathrm{Cm}^{\mathrm{R}}$ & This study \\
\hline pPA01pilE & pBBR1MCS carrying PA01 pile, $\mathrm{Cm}^{\mathrm{R}}$ & This study \\
\hline pUCP22 & Broad-host range cloning vector, $\mathrm{Gm}^{\mathrm{R}}$ & [30] \\
\hline pUCP(D1585pilA) & pUCP22 carrying D1585 pilA, $\mathrm{Gm}^{\mathrm{R}}$ & This study \\
\hline pUCP(PA01pilA) & pUCP22 carrying PA01 pilA, $\mathrm{Gm}^{\mathrm{R}}$ & This study \\
\hline pUCP(280pilA) & pUCP22 carrying 280 pilA, $\mathrm{Gm}^{\mathrm{R}}$ & This study \\
\hline pUCP(D1585pilE) & pUCP22 carrying D1585 pile, $\mathrm{Gm}^{\mathrm{R}}$ & This study \\
\hline pUCP(PA01pile) & pUCP22 carrying PA01 pilE, $\mathrm{Gm}^{\mathrm{R}}$ & This study \\
\hline $\mathrm{pEX18Tc}$ & $\mathrm{Tc}^{\mathrm{R}}$, oriT, $s a c B$, gene replacement vector & [31] \\
\hline pD1585 $\Delta$ pilA & pEX18Tc, 2 kb $\Delta$ pilA D1585 region & This study \\
\hline p280 2 pilA & pEX18Tc, 2 kb $\Delta$ pilA 280 region & This study \\
\hline
\end{tabular}

\subsection{Transposon Mutant Library Receptor Screen}

A 2242 member P. aeruginosa PA01 random-insertion mini-Tn5-luxCDABE transposon mutant library [20] was screened for resistance to DLP1 phage infection using a spotting assay. $100 \mu \mathrm{L}$ overnight culture was spread on 1/2 LB solid medium and allowed to dry. $10 \mu \mathrm{L}$ of DLP1 was spotted in duplicate, as well as $10 \mu \mathrm{L}$ of phage $\varphi \mathrm{KZ}$ and $1 / 2 \mathrm{LB}$ as positive and negative controls, respectively. Plates were incubated overnight at $30^{\circ} \mathrm{C}$ and examined for absence of DLP1 clearing the following day. High titer phage stocks of $10^{10} \mathrm{pfu} / \mathrm{mL}$ were used. 


\subsection{Phage Plaquing Assays}

DLP1 and DLP2 plaquing ability was determined by spotting on bacterial soft agar overlays. Briefly, $100 \mu \mathrm{L}$ of overnight culture was mixed with $3 \mathrm{~mL}$ of $0.7 \%$ 1/2 LB top agar, overlaid onto $1 / 2 \mathrm{LB}$ plates with or without antibiotics and allowed to dry at room temperature for 30 min. Phage stocks were standardized to $10^{10} \mathrm{PFU} / \mathrm{mL}$ on S. maltophilia D1585 and tenfold serially diluted in SM to $10^{3} \mathrm{PFU} / \mathrm{mL} .5 \mu \mathrm{L}$ of each dilution was spotted onto the prepared plates and incubated for $18 \mathrm{~h}$ at $30{ }^{\circ} \mathrm{C}$. Each experiment was repeated in biological and technical triplicate.

\subsection{Construction of $\triangle$ pilA S. maltophilia D1585 and 280 Mutants}

The major pilin subunit, pilA, was identified in S. maltophilia D1585 by sequence homology to pilA in P. aeruginosa PA01 using Geneious (10.1.3) [32], and was subsequently used to identify the pilA ortholog in S. maltophilia 280 . The amino acid sequence percent identity of pilin subunits were compared using MUSCLE [33,34]. The S. maltophilia D1585 and 280 clean deletion pilA mutants were constructed by allelic exchange [35] as described below, using primers listed in Supplementary Table S1.

Two separate PCRs were performed to amplify DNA fragments 1096 bp and 955 bp in length, corresponding to regions upstream and downstream of the pilA gene in D1585, respectively, with 30 nucleotides of overlap at the $3^{\prime}$ and $5^{\prime}$ ends. Primers were designed from a $6361 \mathrm{bp}$ contig containing the pilA gene, as the D1585 genome assembly is currently incomplete. The sequence upstream to the region to be deleted was amplified from D1585 genomic DNA using primers SmpilAupF and SmpilAupR-OE. The sequence downstream of the deletion was amplified from D1585 genomic DNA using primers SmpilAdownF-OE and SmpilAdownR. Primers to delete pilA in S. maltophilia 280 were designed similarly from an 111,798 bp contig containing pilA, as the 280 -genome assembly is also incomplete. The region upstream of the deletion was amplified from 280 genomic DNA using primers 280pilAupR and 280pilAupF-OE, producing a 1074 bp product. The downstream region was amplified using primers 280pilAdownR-OE and 280pilAdownF, producing a 1,146 bp product. The PCR mixture contained $50 \mathrm{ng}$ D1585 genomic DNA, $0.5 \mu \mathrm{M}$ of each primer, $0.2 \mathrm{mM}$ dNTPs, 3\% DMSO and $1 \times$ GC Buffer (New England Biolabs, Mississauga, ON, Canada) in sterile milliQ water and was heated for $3 \mathrm{~min}$ at $98{ }^{\circ} \mathrm{C}$ before the addition of $1 \mathrm{U}$ of Phusion High-Fidelity DNA Polymerase (New England Biolabs) per reaction. The reactions were then processed for 35 cycles of $15 \mathrm{~s}$ at $98{ }^{\circ} \mathrm{C}, 30 \mathrm{~s}$ at $57.4{ }^{\circ} \mathrm{C}$ for D1585 or $66.7^{\circ} \mathrm{C}$ for 280 , and $30 \mathrm{~s}$ at $72{ }^{\circ} \mathrm{C}$ before a final extension of $10 \mathrm{~min}$ at $72{ }^{\circ} \mathrm{C}$. The PCR products were purified using a QIAquick PCR purification kit (Qiagen, Inc., Germantown, MD, USA).

Overlap extension PCR [36] was used to join the upstream and downstream PCR products, creating a $2021 \mathrm{bp}$ template for D1585 and a $2190 \mathrm{bp}$ template for 280. Briefly, a 1:1 ratio of upstream and downstream template was added to a PCR mixture lacking primers and processed for $3 \mathrm{~min}$ at $98^{\circ} \mathrm{C}$, during which time Phusion polymerase was added, followed by 35 cycles of $15 \mathrm{~s}$ at $98{ }^{\circ} \mathrm{C}, 30 \mathrm{~s}$ at $67.8^{\circ} \mathrm{C}$ for D1585 and $65.3^{\circ} \mathrm{C}$ for 280 , and $1 \mathrm{~min}$ at $72{ }^{\circ} \mathrm{C}$ before a final extension of $10 \mathrm{~min}$ at $72{ }^{\circ} \mathrm{C}$. A 1:1 ratio of primers SmpilAupF and SmpilAdownR or 280pilAupR and 280pilAdownF was added to the reaction after 10 cycles, which allowed the upstream and downstream templates to prime off their 30 bp overlap. The $\sim 2 \mathrm{~kb}$ products were purified from a 1\% agarose gel using a Gene Clean II kit (MP Biomedicals, Santa Ana, CA, USA) and digested with SalI and HindIII Fast Digest restriction endonucleases (Thermo Scientific, Waltham, MA, USA). The fragments were cloned into pEX18Tc, yielding pD1585 $\Delta$ pilA containing a $444 \mathrm{bp}$ in-frame deletion within the $477 \mathrm{bp}$ D1585 pilA gene and p280 2 pilA containing a 372 bp in-frame deletion within the 414 bp 280 pilA gene as confirmed by Sanger sequencing. The deletion vectors were transformed into the mobilizing E. coli strain S17-1 and the plasmids were transferred into D1585 or 280 by conjugation as described previously, in a 1:10 donor to recipient ratio [37]. Single crossover D1585 transconjugants carrying pD1585 $\Delta$ pilA in their chromosome were selected on LB agar containing $100 \mu \mathrm{g} / \mathrm{mL}$ tetracycline and merodiploid status was verified by PCR using pilA specific primers, SmpilAF and SmpilAR lacking restriction enzyme tails. Single crossover 280 transconjugants carrying p280 $\Delta$ pilA were selected on LB agar containing $50 \mu \mathrm{g} / \mathrm{mL}$ tetracycline and merodiploid status was verified by PCR using pilA specific 
primers, 280pilAF and 280pilAR lacking restriction enzyme tails. Positive transconjugants were grown in the absence of tetracycline for $2 \mathrm{~h}$ to allow for a second crossover and screened on LB agar containing $10 \%(w / v)$ sucrose. Sucrose-resistant colonies appearing after $48 \mathrm{~h}$ incubation at $37^{\circ} \mathrm{C}$ were screened for the presence of the pilA deletion using the pilA specific primer pairs.

\subsection{Complementation of Pilus Mutants}

The pilA and pilE genes were amplified from P. aeruginosa PA01 by colony PCR using primer pairs PapilAF and PapilAR, and PapilEF and PapilER respectively, and from S. maltophilia D1585 genomic DNA by PCR using primer pairs SmpilAF and SmpilAR, and SmpilEF and SmpilER, as listed in Supplementary Table S1. The pilA gene was amplified from S. maltophilia 280 genomic DNA by PCR using primer pairs 280pilAF and 280pilAR. The resulting products were digested with SalI and HindIII, or BamHI and HindIII Fast Digest restriction endonucleases (Thermo Scientific) and ligated using T4 DNA ligase (NEB) into the vector pUCP22 [30] for expression in PA01, or pBBR1MCS [29] for expression in D1585 and 280. The resulting constructs as listed in Table 1 were verified by Sanger sequencing and subcloned into electrocompetent E. coli DH5 $\alpha$ before transforming P. aeruginosa PA01 and S. maltophilia D1585 and 280 mutants by electroporation.

Electrocompetent P. aeruginosa PA01 cells were prepared as described by Choi et al. (2006) [38] with some modifications. Briefly, overnight cultures of PA01 grown in LB at $37^{\circ} \mathrm{C}$ were harvested by centrifugation for $5 \mathrm{~min}$ at $8000 \times g$ and were washed 3 times with $300 \mathrm{mM}$ sucrose. The cell pellet was resuspended in the remaining $300 \mathrm{mM}$ sucrose and competent cells were stored in $100 \mu \mathrm{L}$ aliquots at $-80{ }^{\circ} \mathrm{C}$ prior to use. Electrocompetent $S$. maltophilia D1585 and 280 cells were prepared as described by Ye et al. (2014) [39]. Overnight cultures were subcultured and grown to an optical density at $600 \mathrm{~nm}\left(\mathrm{OD}_{600}\right)$ of $1.0 \mathrm{in} \mathrm{LB}$ at $37^{\circ} \mathrm{C}$ and placed on ice for $30 \mathrm{~min}$. The chilled cells were harvested by centrifugation for $5 \mathrm{~min}$ at $4000 \times g$ and $4{ }^{\circ} \mathrm{C}$ and washed 3 times with ice-cold $10 \%$ glycerol $(v / v)$. The competent cells were resuspended in residual $10 \%$ glycerol and stored in $100 \mu \mathrm{L}$ aliquots at $-80{ }^{\circ} \mathrm{C}$ prior to use. Electrocompetent E. coli $\mathrm{DH} 5 \alpha$ cells were prepared similarly to S. maltophilia; however, subcultures were grown to an $\mathrm{OD}_{600}$ of $0.5-0.7$ at $37^{\circ} \mathrm{C}$.

\subsection{Transmission Electron Microscopy}

Bacterial samples were prepared for electron microscopy as follows. Overnight cultures were diluted 1:20 in fresh 1/2 LB broth and grown to an $\mathrm{OD}_{600}$ of $0.3-0.6$ at $30{ }^{\circ} \mathrm{C}$ with shaking. $1 \mathrm{~mL}$ of subculture was harvested at $15,000 \times \mathrm{g}$, fixed in EM fixative (2.5\% glutaraldehyde, $2 \%$ paraformaldehyde, $0.1 \mathrm{M}$ phosphate buffer, pH 7.2) for $30 \mathrm{~min}$, and resuspended in $1 \times$ phosphate-buffered saline (PBS), $\mathrm{pH}$ 7.4. For visualization of bacteria, a carbon-coated copper grid was incubated with $10 \mu \mathrm{L}$ of sample for $2 \mathrm{~min}$ and stained with $2 \%$ phosphotungstic acid (PTA) for $10 \mathrm{~s}$. To visualization phage binding, the bacterial samples were mixed in a 1:2 ratio with high titer $10^{10} \mathrm{pfu} / \mathrm{mL}$ phage stock for $2 \mathrm{~min} .10 \mu \mathrm{L}$ of this mixture was incubated on the copper grid for $4 \mathrm{~min}$, followed by staining with 2\% PTA. Transmission electron micrographs were captured using a Philips/FEI Morgagni transmission electron microscope with charge-coupled device camera at $80 \mathrm{kV}$ (University of Alberta Department of Biological Sciences Advanced Microscopy Facility).

\subsection{Twitching Motility Assay}

Twitching motility assays were used as an indirect measurement of type IV pili function. A single bacterial colony was suspended in $100 \mu \mathrm{L} \mathrm{LB}$ broth and stab inoculated with a toothpick through a $3 \mathrm{~mm}$ thick LB agar layer (1\% agar), containing $0.3 \%$ porcine mucin or antibiotic where indicated, to the bottom of the petri dish and incubated with humidity at $37^{\circ} \mathrm{C}$ for $24 \mathrm{~h}$ for PA01 [40] or $72 \mathrm{~h}$ for D1585 [41]. Twitching motility zones between the agar and petri dish interface were visualized by gently removing the agar and staining each plate with $1 \%(w / v)$ crystal violet for 30 min followed by rinsing excess stain away with water. Stained twitching zone areas were measured using ImageJ 
software (NIH, Bethesda, MD, USA) [42]. Each strain was tested in biological and technical triplicate and average twitching area was calculated from the nine twitching zones.

\subsection{Bioinformatic Analysis}

Experimentally determined pili-binding Siphoviridae phages were identified in a search of the literature and the corresponding genomic sequence was used to perform a conserved domain search (CD-search) [43] to identify the potential presence of a phage-tail_3 domain which is found within gp26 (central tail hub) of DLP1 and DLP2. The CD-search database CDD v3.16-50369 PSSMs was used to identify phage-tail_3 domains above the expected E-value threshold of 0.01. Composition-based statistics adjustment was used. The identified protein featuring the phage-tail_3 domain for each phage was then used for a multiple sequence alignment to include DLP1 and DLP2 using the MUSCLE [33,34] plugin for Geneious [32]. Two multiple sequence alignments were also performed with the top 10 BLASTP hits for gp26 of DLP1 and DLP2. For each MUSCLE alignment, the maximum number of iterations selected was 8 , with the anchor optimization option selected. The trees from iterations 1 and 2 were not retained. The distance measure for iteration 1 was kmer6_6 and was pctid_kimura for subsequent iterations. The clustering method was UPGMB for all iterations.

\section{Results and Discussion}

\subsection{P. aeruginosa PA01 Type IV Pilus Mutants Are Resistant to DLP1 Infection}

Bacteriophage DLP1 is a broad host range phage capable of lysing eight out of $27 \mathrm{~S}$. maltophilia and two out of 19 P. aeruginosa strains tested, one being the reference strain PA01 [17]. A spotting screen of 2242 PA01 mutants with random mini-Tn5-luxCDABE transposon insertions causing polar mutations [20] identified 27 mutants (Supplementary Table S2) with insertions in 11 different genes that were resistant to DLP1 infection (Table 2). Ten of the 11 genes disrupted are directly involved in type IV pilus biogenesis, including both structural components, pilB, pilE, pilT, pilV, pilY1, and fimV, and regulatory components, pilJ, pilR, pilS, and algR. The additional gene, PA2806, encodes a conserved hypothetical protein, with homology to QueF, an NADPH-dependent 7-cyano-7-deazaguanine reductase enzyme involved in queuosine biosynthesis, with unknown function related to pilus biogenesis. While the pilus related genes identified in the mutant library cover only a fraction of the over 40 genes involved in type IV pilus biogenesis and function in P. aeruginosa [44], there were no other pilus mutants in the library to screen for DLP1 sensitivity.

To better identify the type IV pilus as the receptor for DLP1 infection of PA01, additional PAO1 pilus mutants were obtained $[21,22]$ and screened. These included transposon mutants of the major pilin subunit PilA, the outer membrane pore subunit PilQ, and additional structural subunits PilF, PilN and PilU (Table 2). As expected, these mutants were also resistant to DLP1 infection; however, the pilU mutant was not. Similar results have been observed following infection of mutant P. aeruginosa strains PA01 and PAK by another pilus-dependent Siphoviridae bacteriophage, P04; the unpiliated pilB and hyperpiliated pilT mutants are resistant to phage infection, whereas the hyperpiliated pilU mutant remains susceptible [45]. These genes encode the three ATPases that are responsible for extension and retraction of the type IV pilus; PilB is involved in polymerization of pilin subunits, and PilT and PilU are involved in depolymerization [46]. Assembly and disassembly of the pilus allows bacteria to move across a surface, a process known as twitching motility. While PilT and PilU appear to have similar functions, only pill mutants have the unusual combination of pilus-specific phage susceptibility and loss of twitching motility $[45,46]$. Assessment of twitching motility in each of the 27 DLP1 resistant PA01 mutants, as well as the pilU mutant, revealed that all lack a twitching zone and therefore functional pili, except for the PA2806 mutant. These findings mirror what others have observed for pilus-specific phages P04, B3, and D3112 [45], and support the hypothesis that DLP1 uses the type IV pilus for first contact with its host and requires a pilus functionally capable of retraction in order to infect. 
Table 2. P. aeruginosa PA01 genes involved in type IV pilus biogenesis and DLP1 phage infection identified by a transposon mutant library screen.

\begin{tabular}{|c|c|c|c|c|}
\hline Number of Mutants & Gene Affected & Function & DLP1 Lysis & Source \\
\hline 2 & pilA & Major pilin subunit & - & [21] \\
\hline 4 & pilB & Cytoplasmic ATPase/pilin polymerase & - & [20] \\
\hline 3 & pile & Minor pilin subunit & - & {$[20]$} \\
\hline 1 & pilF & Outer membrane pilotin; controls secretin localization & - & {$[21]$} \\
\hline 1 & pilJ & Involved in pilus assembly & - & [20] \\
\hline 1 & pilN & Inner membrane assembly protein & - & [21] \\
\hline 2 & pilQ & Secretin monomer; forms outer membrane pore & - & {$[21]$} \\
\hline 1 & pilR & $\begin{array}{l}\text { Cytoplasmic response regulator of two-component } \\
\text { system; regulates PilA expression }\end{array}$ & - & [20] \\
\hline 4 & pils & $\begin{array}{l}\text { Inner membrane histidine kinase of two component } \\
\text { system; regulates PilA expression }\end{array}$ & - & [20] \\
\hline 2 & pilT & Cytoplasmic ATPase; pilin depolymerase & - & [20] \\
\hline 1 & pill & Cytoplasmic ATPase; regulation of pilus retraction & + & [21] \\
\hline 2 & pilV & Minor pilin subunit & - & [20] \\
\hline 4 & pilY1 & Possible adhesin; regulates pilus retraction & - & [20] \\
\hline 3 & fimV & Inner membrane protein; aids in secretin assembly & $+1-$ & {$[20]$} \\
\hline 1 & $\operatorname{alg} R$ & Regulates expression of minor pilin operon & $+/-$ & [20] \\
\hline 1 & PA2806 & Conserved hypothetical protein & - & {$[20]$} \\
\hline
\end{tabular}

Strain characteristics: +, phage sensitivity; -, phage resistance; +/-, DLP1 low efficiency of plating.

\subsection{Complementation in P. aeruginosa Restores DLP1 Infectivity}

To confirm that PA01 mutants were resistant to DLP1 infection due to their lack of pili, the two major subunit pilA and three minor subunit pilE mutants were chosen as hosts for complementation analysis and to assess DLP1 infectivity via phage plaquing assays. In PA01, pilE is the seventh gene in the minor pilin operon and pilA is transcribed as a single gene, therefore polar mutations are not a concern for complementation of these mutants. Wildtype PA01 is susceptible to DLP1 but not DLP2, clearing at $10^{9} \mathrm{PFU} / \mathrm{mL}$ (Figure 1). Both pilA mutants, PW8621 and PW8622, are resistant to DLP1 infection and when transformed with the endogenous PA01 pilA gene, exhibit restored susceptibility to DLP1 infection. DLP1 deposited on bacterial lawns of the complemented pilA mutants produce clear spots comparable to wildtype levels. The same effect was observed for each of the three PA01 pilE mutants transformed with pUCP22 carrying the endogenous pilE gene. In comparison, transformation of each mutant with an empty pUCP22 vector did not restore DLP1 infection and no lysis of the bacterial lawn was observed. As confirmation that DLP1 binds type IV pili expressed on the surface of PA01, transmission electron microscopy (TEM) was used to visualize this interaction. Imaging of log phase PA01 cells mixed with high titer DLP1 showed phage particles near the cell surface that appeared to interact with the base of a pilus via the phage tail (Figure 2a). This observation, along with complementation restoring phage infectivity, confirms the pilus as phage DLP1's initial point of attachment to P. aeruginosa PA01.

To determine whether DLP1 also uses the type IV pilus as the first point of contact with its S. maltophilia hosts, we performed cross-genera complementation experiments using the PA01 minor pilin, pilE, and major pilin, pilA, orthologs in strain D1585 expressed in the respective PA01 mutant. Both DLP1 and DLP2 were isolated on S. maltophilia strain D1585, and out of the 27 strains tested, both phages infect D1585 with equally high efficiency, producing plaques when spotted at $10^{3} \mathrm{PFU} / \mathrm{mL}$ [17]. Therefore, we describe D1585 as the major host for DLP1 and DLP2 in our S. maltophilia strain collection. Similar to complementation with the endogenous PA01 genes, cross-genera complementation of the PA01 pilA mutants PW8621 and PW8622 with D1585 pilA also restored DLP1 infection. Exposure of these cross-genera complemented PA01 mutants to DLP1 produced infection at the same efficiency of plating as wildtype PA01; however, DLP1 appears to clear the bacterial lawn expressing D1585 pilA more effectively (Figure 1). DLP1 infects S. maltophilia D1585 at higher efficiency of plating, plaquing at $10^{3} \mathrm{PFU} / \mathrm{mL}$, as compared to P. aeruginosa PA01 that DLP1 is unable to infect at a PFU per mL lower than $10^{8}$. It is likely that DLP1 binds amino acids in the PilA of D1585 with more affinity than the PilA of PA01. Therefore, expression of the D1585 pilA subunit in a pilA deficient PA01 strain permits more 
efficient DLP1 receptor binding and infection, which produces more clear spots in the bacterial lawn. Alternatively, cross-genera complementation of the three PA01 pilE mutants with D1585 pilE produces only partial infection by DLP1, showing a slightly thinned lawn at $10^{10} \mathrm{PFU} / \mathrm{mL}$ (Figure 1). The pilE gene encodes one of four minor pilin subunits in P. aeruginosa that assemble together at the tip of the pilus, along with FimU and PilY1, to prime pilus assembly [47]. P. aeruginosa strains express one of five major type IV pilin alleles with an associated set of minor pilin alleles [48,49]. Studies have shown that the minor pilin genes are compatible with major pilins of the same group, but do not function as well when expressed with a heterologous major pilin [49]. Because the PA01 and D1585 PilA subunits and PilE subunits share only $51 \%$ and $43 \%$ amino acid sequence identity, respectively, it is possible that the major pilin pilA subunits are sufficiently different between P. aeruginosa PA01 and S. maltophilia D1585 that the D1585 PilE minor subunit does not have high affinity for the PA01 PilA major subunit. This may decrease the association between the minor pilin priming complex and PilA such that the pilus does not assemble proficiently, resulting in decreased piliation or inefficient pilus extension and decreased phage infection, as observed, due to loss of receptor expression. Examination of twitching motility in each of the complemented strains supports this hypothesis, showing that pili function is reduced by approximately $61 \%$ and $58 \%$ for D1585 pilA and pilE cross-genera complementation respectively, compared to complementation with the PA01 endogenous subunits (Figure 3 ). While the overall pili function is similar between D1585 piE and pilA complemented PA01 mutants, differences in phage infectivity may be explained by changes in amino acids between the foreign and endogenous subunits. This is similar to observations by Giltner et al. 2011; P. aeruginosa PA01 Group II pilE mutants complemented with a PA14 Group III pilE gene in trans decreased twitching motility by $9 \%$ relative to endogenous complementation [49]. Because the amino acid sequence identity of PA01 and D1585 PilE subunits is lower than PA01 and PA14 PilE products that share 51\% amino acid identity, our substantial decrease in twitching motility is likely due to the inefficient assembly of D1585 PilE with the PA01 pilin subunits.

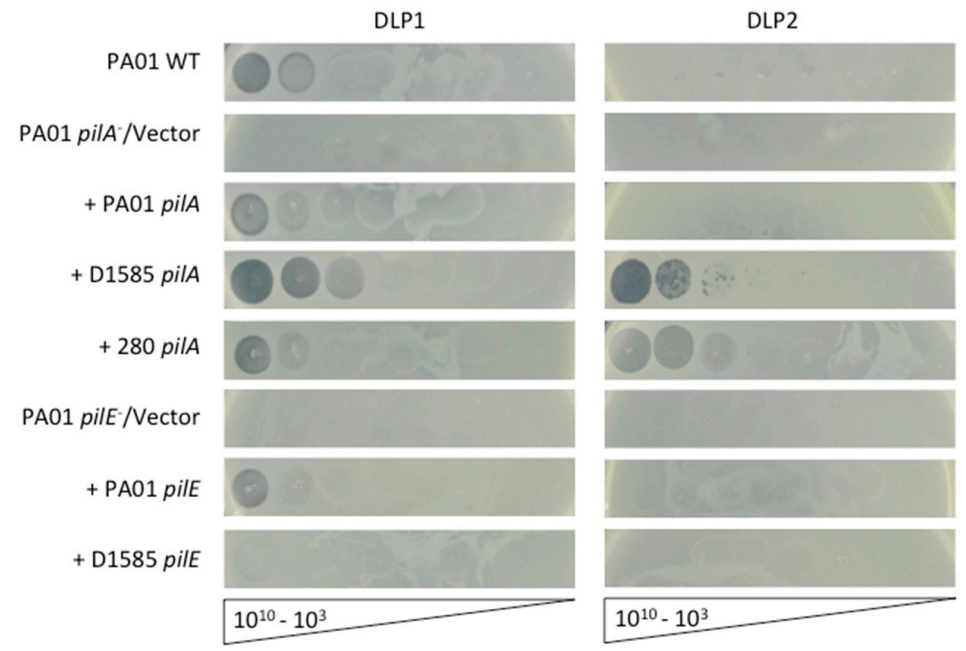

Figure 1. Infection of P. aeruginosa PA01 expressing varying pilin subunits by DLP1 and DLP2. PA01 wildtype (WT) is susceptible to DLP1, while the PA01 pilA PW8621 and pilE PA01_lux_41_C7 mutants are resistant to infection. Complementation of PA01 mutants with the endogenous genes restores DLP1 infectivity to wildtype levels, clearing at $10^{9} \mathrm{PFU} / \mathrm{mL}$. Cross-genera complementation with the S. maltophilia D1585 pilA gene restores infection by DLP1, clearing at $10^{8} \mathrm{PFU} / \mathrm{mL}$, and allows DLP2 plaquing at $10^{7} \mathrm{PFU} / \mathrm{mL}$. Complementation with the D1585 pilE gene allows partial DLP1 infection. Cross-genera complementation with the S. maltophilia 280 pilA gene also allows DLP2 infection at $10^{8} \mathrm{PFU} / \mathrm{mL}$ and partially restores DLP1 infectivity. Images are representative of three biological replicates, each with three technical replicates. Similar results were observed for the additional pilA and pilE mutants when complemented. 


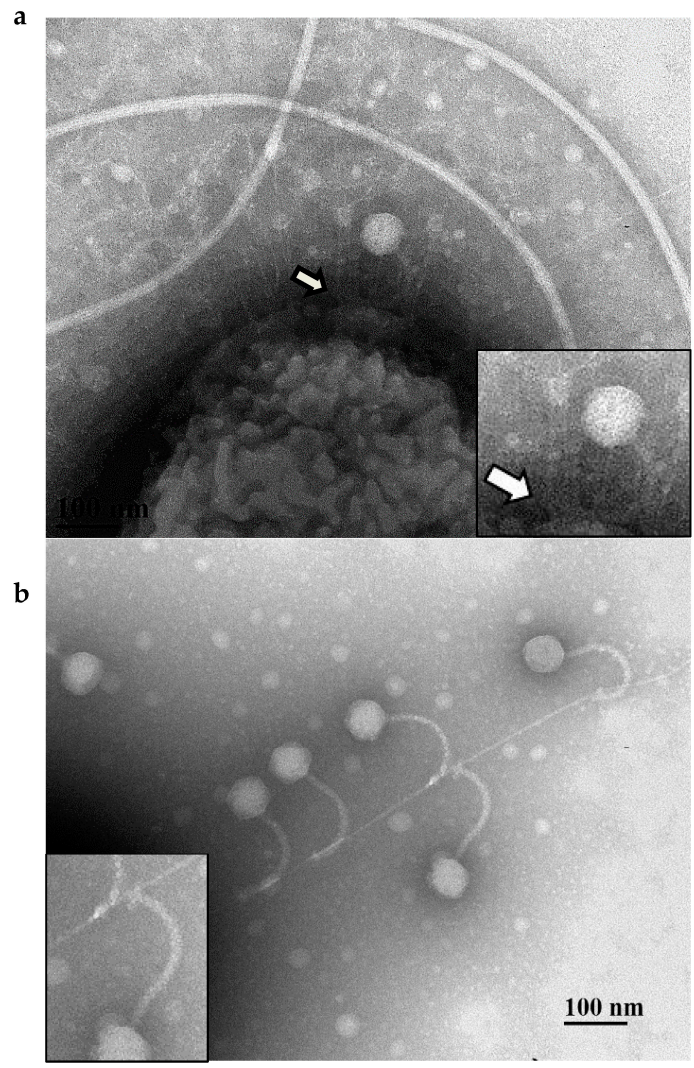

Figure 2. DLP1 interacts with pili on the cell surface of wildtype S. maltophilia D1585 and P. aeruginosa PA01. Electron micrographs showing (a) multiple pili projecting from the pole of a PA01 cell with a single DLP1 phage interacting with the base of a pilus (arrow). Cells and phage were stained with $2 \%$ phosphotungstic acid and visualized at 110,000-fold magnification by transmission electron microscopy. (b) Five DLP1 phage binding a single pili extending from the pole of a D1585 cell. Inset images show closer view of phage-pili interactions. Cells and phage were at 110,000-fold magnification.

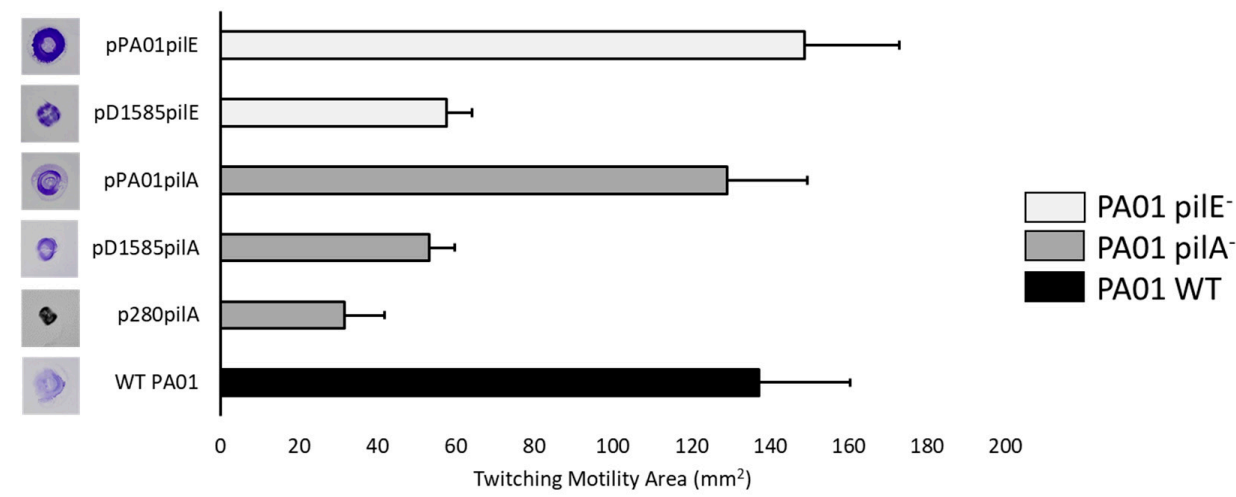

Figure 3. Twitching motility is partially restored in cross-genera complemented P. aeruginosa PA01 pilin mutants. PA01, its pilA PW8621 and pilE PA01_lux_41_C7 mutants and their respective complemented strains were stab inoculated through 1\% 1/2 LB agar and incubated for $24 \mathrm{~h}$ at $37^{\circ} \mathrm{C}$. Twitching zones were visualized with $1 \%$ crystal violet and measured using ImageJ [42]. Complementation with the endogenous PA01 genes restored twitching to wildtype, while cross-genera complementation only partially restored motility. Representative twitching zones are shown on the left and the average area of the twitching zones from nine replicates are shown on the right including error bars showing standard deviation. 
A second S. maltophilia phage, DLP2, was tested against the pilA cross-genera complemented strains PW8621 and PW8622 carrying D1585 pilA on pUCP22. DLP2 is another broad host range phage that is capable of infecting nine out of 27 S. maltophilia strains, including D1585, and two out of 19 P. aeruginosa strains, although PA01 is not one of them [17]. Phage spotting shows that DLP2 can infect pilA deficient PA01 mutants expressing the D1585 pilA gene, clearing the bacterial lawn at $10^{9} \mathrm{PFU} / \mathrm{mL}$ (Figure 1). This is not entirely surprising given that DLP2 can infect two different strains of P. aeruginosa, HER1004 and 14,715 [17], suggesting that there are no intracellular blocks to phage infection across these genera once a primary receptor for DLP2 is expressed on the cell surface. DLP1 and DLP2 are closely related phages, sharing a high degree of sequence identity over their genomes [17]. Because both are capable of infecting S. maltophilia D1585 as a major host, it is possible if not probable that they share the same receptor. These results suggest that DLP2 also uses the type IV pilus as the primary receptor for infection of D1585, requiring only the D1585 major pilin expressed in trans to infect the previously resistant strain, P. aeruginosa PA01. However, it is then unclear why the host ranges of DLP1 and DLP2 differ, and how these two phages adhere to pilin subunits of different hosts if they both do adhere to the PilA subunit to infect D1585. Rescue of phage infection through cross-genera complementation of the major pilin subunit also suggests that the pre-pilin signal cleavage sequence of D1585 pilins is conserved and recognized by P. aeruginosa pre-pilin peptidase, allowing proficient assembly of mature pilins sufficient for phage recognition and infection.

Based upon the similarity between pilin subunits and the highly conserved nature of type IV pili assembly machinery, heterologous expression of type IV pilins has been used to analyze structure-function relationships of pili in several pathogenic bacteria. Research shows that P. aeruginosa can assemble exogenous pilins from species including Dichelobacter nodosus, Moraxella bovis, Neisseria gonorrhoeae, and Escherichia coli [50-53]. Heterologous expression of pili subunits restores pili function and associated phenotypes, such as natural competence and phage binding [54-56]. For example, the major pilin subunit PilA from P. aeruginosa can be successfully expressed and assembled into functional type IV pili in N. gonorrhoeae, and is sufficient for P. aeruginosa specific phage PO4 binding, determined through transmission electron microscopy [57]. In contrast to our cross-genera complementation, many of these studies use retraction-deficient pilT- strains of P. aeruginosa to compensate for low steady-state expression of pili. However, such a technique would inhibit DLP1 and DLP2 infection of the host, as these phages appear to require pili retraction by the host to reach the cell surface. While pilin sequences vary within species, the type IV pilus assembly machinery is widely conserved at the nucleotide level, providing relaxed specificity for the heterologous expression of pilin proteins from distantly related species [49]. This insensitivity to sequence changes in PilA provides an evolutionary benefit to the cell, allowing the incorporation of a wide range of pilins for antigenic variation and functional diversity.

\subsection{Deletion of pilA in S. maltophilia D1585 Prevents DLP1 and DLP2 Infection}

Following on the results obtained from cross-genera complementation that implicated the type IV pilus in D1585 as the receptor for DLP1 and DLP2, the major subunit pilA ortholog was deleted in S. maltophilia D1585 using overlap-extension PCR and allele exchange to create a clean deletion. Sanger sequencing confirmed the in-frame clean deletion and twitching motility was subsequently examined in both wildtype D1585 and the $\Delta$ pilA mutant to analyze pili function. D1585 wildtype produces a small zone of twitching, averaging $25 \pm 10 \mathrm{~mm}^{2}$ after $72 \mathrm{~h}$ incubation at $37^{\circ} \mathrm{C}$. This twitching zone is absent in the D1585 $\triangle$ pilA mutant, indicating that the mutant cannot assemble functional type IV pili, and suggests that the deleted gene encodes the major type IV pilin subunit in D1585. While the sizes of twitching motility zones vary greatly in both clinical and environmental S. maltophilia strains $[7,41]$, our D1585 wildtype strain did not consistently produce twitching zones. To further confirm that the D1585 $\Delta$ pilA mutant was incapable of twitching motility, we induced pili expression in both the wildtype and mutant strains by adding mucin to the media. Mucin is a major component of mucus produced in the lungs where S. maltophilia can colonize and has been shown to increase the expression of type IV 
pili in P. aeruginosa resulting in increased twitching motility zones [58]. The addition of $0.3 \%$ mucin to the twitching motility plates increased D1585 wildtype twitching zones to approximately $41 \pm 14 \mathrm{~mm}^{2}$ after only $24 \mathrm{~h}$ incubation. This increase in motility, while also inconsistent, was completely absent in the $\triangle$ pilA mutant, indicating that the mutant does not express functional pili.

Assessment of the phage plaquing ability on the constructed D1585 $\Delta$ pilA mutant by spot assay shows that the mutant is resistant to infection by DLP1 and DLP2, displaying an absence of clearing and cell lysis at high phage titer (Figure 4). Complementation of the mutant with the endogenous D1585 pilA gene restored infection by DLP1 and DLP2 to wildtype levels, each producing plaques at $10^{3} \mathrm{PFU} / \mathrm{mL}$, as expected for type IV pili-specific bacteriophages. Transformation of D1585 $\triangle$ pilA with an empty pBBR1MCS vector did not restore phage infection and no change in bacterial growth in each phage spot was observed. In contrast to the original characterization of DLP1 by Peters et al. (2015) [17], high titer phage stocks of $10^{10} \mathrm{PFU} / \mathrm{mL}$ were able to clear the bacterial lawn and plaque formation was no longer delayed. We suspect that the efficiency of DLP1 infection has increased since its original isolation due to repeated propagation on the S. maltophilia host D1585 under laboratory conditions. These results confirm the identification of the type IV pilus as the primary receptor for DLP1 and DLP2 infection of their shared host, D1585. Because DLP1 can infect both D1585 and PA01 via adherence to the type IV pilus, we hypothesized that expression of the exogenous PA01 pilA gene in our D1585 $\triangle$ pilA mutant should restore DLP1 binding and infection, similar to the reverse situation as described above. As expected, cross-genera complementation of the D1585 $\Delta$ pilA mutant with the cloned PA01 pilA gene produced less efficient DLP1 infection, forming plaques when spotted with $10^{7} \mathrm{PFU} / \mathrm{mL}$ DLP1 (Figure 4). Surprisingly, DLP2 was also capable of low-level infection of D1585 $\Delta$ pilA expressing the PA01 major pilin subunit; DLP2 produced plaques at $10^{9} \mathrm{PFU} / \mathrm{mL}$, approximately $10^{2}$-fold lower efficiency than DLP1. While DLP2 is unable to infect wildtype PA01, it is possible that the PA01 PilA subunit folds differently in D1585 to expose different phage binding sites and enable low levels of DLP2 infection. Alternatively, PA01 PilA may interact with the pilus priming minor pilin subunits of D1585 as efficiently as the endogenous major subunit, perhaps permitting DLP2 to recognize the pili via the minor pilins and reach a surface secondary receptor for partial infection. Twitching motility analysis of the complemented D1585 mutant yielded no changes in motility compared to the low levels observed in wildtype D1585.

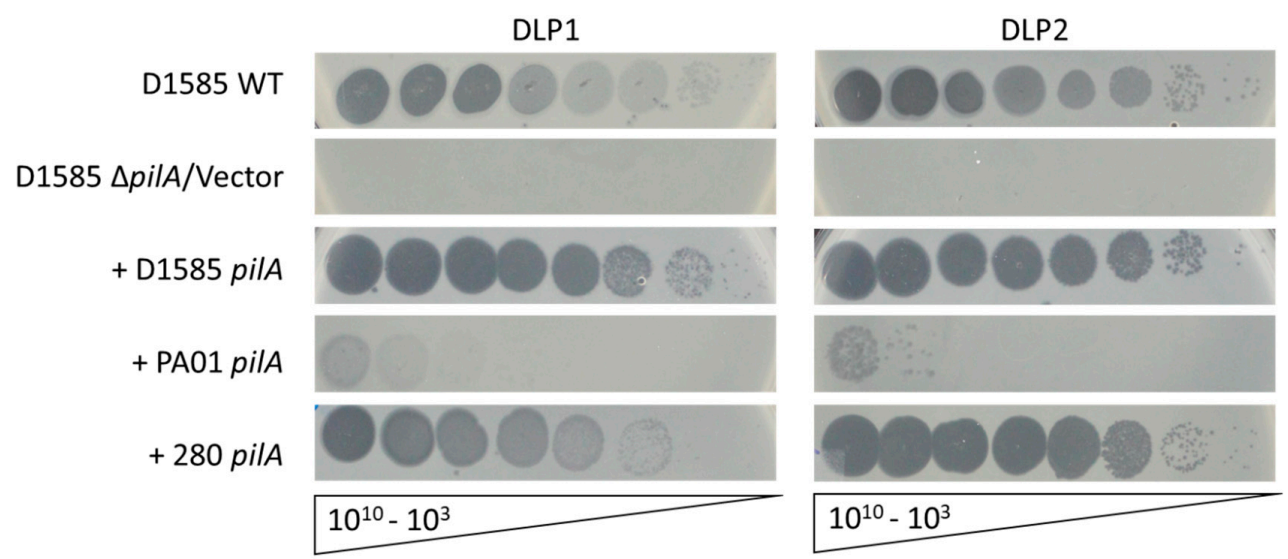

Figure 4. Infection of S. maltophilia D1585 expressing varying pilin subunits by DLP1 and DLP2. D1585 wildtype (WT) is susceptible to DLP1 and DLP2, while the D1585 $\triangle$ pilA mutant is resistant to both phages. Complementation of D1585 $\triangle$ pilA with the endogenous pilA gene restores DLP1 and DLP2 infectivity to wildtype levels, each plaquing at $10^{3} \mathrm{PFU} / \mathrm{mL}$. Cross-genera complementation with the P. aeruginosa PA01 pilA gene restores partial infection by DLP1 and DLP2, plaquing at $10^{7}$ and $10^{9}$ respectively. Cross-species complementation with the S. maltophilia 280 pilA gene restores DLP2 infection to wildtype levels, and partially restores DLP1 infectivity, showing plaquing at $10^{5}$. Images are representative of three biological replicates, each with three technical replicates. 
TEM visualization of log phase D1585 cells mixed with high titer DLP1 confirmed that DLP1 binds the type IV pilus of D1585. The S. maltophilia D1585 viewed expressed multiple pili from their poles; however, the pilus morphology differed from P. aeruginosa PA01; D1585 pili were longer and thicker than the fine projections viewed on PA01 (Figure 2). Cells mixed with DLP1 clearly showed phage particles distributed tail first along D1585 type IV pili filaments, with phage appearing to attach to the sides of the pili via the tail fibers, confirming that DLP1's initial point of attachment to S. maltophilia D1585 is the type IV pilus (Figure 2b). In addition to PA01 pili being finer than those of D1585, they were also on average shorter. It is possible that the length of the pili affects the susceptibility of these strains to DLP1 and DLP2. Attempts to visualize DLP2 binding the pili of D1585 were unsuccessful.

\subsection{Deletion of pilA in S. maltophilia 280 Prevents DLP2 Infection}

As described above, DLP1 and DLP2 infection of S. maltophilia D1585 relies on the presence of the type IV pilus for cell surface attachment. To verify that DLP2 uses the type IV pili across its host range and possibly explain differences in the host ranges of DLP1 and DLP2, we examined the S. maltophilia strain 280 that is highly susceptible to DLP2 but not DLP1. S. maltophilia 280 expresses functional pili, demonstrated by a twitching motility zone approximately $155 \mathrm{~mm}^{2}, 6$-fold greater than D1585, following $72 \mathrm{~h}$ incubation (Figure 5a). This twitching zone also increased in size when examined on media containing $0.3 \%$ mucin, similarly to D1585, increasing to $250 \pm 22 \mathrm{~mm}^{2}$ after $24 \mathrm{~h}$ incubation. Log phase 280 cells viewed by TEM revealed long pili projections from the sides of the cells rather than from the poles. These pili were similar in length and diameter to $S$. maltophilia strain D1585; however, attempts to visualize DLP2 interacting with 280 pili or the cell surface have been unsuccessful due to difficulties in preparing clean samples expressing pili.

A $280 \triangle$ pilA mutant was also constructed using overlap extension PCR and allele exchange to delete the D1585 major pilin subunit pilA ortholog. Sanger sequencing of the $1 \mathrm{~kb}$ regions flanking the deletion confirmed the in-frame clean deletion and assessment of twitching motility on plain $1 / 2 \mathrm{LB}$ and $1 / 2$ LB supplemented with $0.3 \%$ mucin revealed the absence of a twitching zone, consistent with a lack of the PilA major pilin subunit and a non-functional type IV pilus. Exposure of the $280 \Delta$ pilA mutant to bacteriophage DLP2 via spot assay showed no evidence of cell lysis, indicating that this mutant is resistant to DLP2 infection, similar to D1585 $\triangle$ pilA (Figure 5b). Complementation of $280 \Delta$ pilA with the endogenous pilA gene restored DLP2 infection to near wildtype levels, producing plaques at $10^{7} \mathrm{PFU} / \mathrm{mL}$ as compared to $10^{5} \mathrm{PFU} / \mathrm{mL}$ on wildtype. These results confirm that DLP2 uses the type IV pilus as its cell surface receptor for infection of S. maltophilia 280 in addition to strain D1585.

Similar to cross-genera complementation of the PA01 pilA mutant with the D1585 pilA gene, expression of the exogenous D1585 pilA gene in our $280 \triangle$ pilA mutant permitted infection by DLP2 as well as DLP1, plaquing at $10^{5} \mathrm{PFU} / \mathrm{mL}$ and $10^{8} \mathrm{PFU} / \mathrm{mL}$ respectively (Figure $5 \mathrm{~b}$ ). The reverse complementation of D1585 $\triangle$ pilA with the 280 pilA also restores DLP1 and DLP2 infection to near wildtype levels, with DLP2 infecting more efficiently (Figure 4, Table 3). Cross-genera complementation of $280 \Delta$ pilA with the P. aeruginosa PA01 pilA gene did not restore infection by either DLP1 or DLP2. This is contrary to the reverse complementation of PA01 pilA mutants with the 280 pilA gene that shows partial infection by DLP2 as well as DLP1 (Figure 1, Table 3). These observations suggest that the P. aeruginosa PA01 PilA subunit does not assemble proficiently with the S. maltophilia 280 type IV pili machinery, whereas the more closely related D1585 PilA subunit can be assembled correctly to allow pili function and phage infection. The amino acid sequence identity between 280 and PA01 PilA subunits is lower than 280 and D1585 PilA, sharing $48 \%$ and $67 \%$ sequence identity respectively. Additionally, the twitching motility zone of $280 \triangle$ pilA carrying pPA01pilA is reduced by $80 \%$ relative to wildtype 280 , compared to complementation with the D1585 or endogenous pilA gene restoring twitching motility to $52 \%$ and $29 \%$ of wildtype respectively (Figure $5 a$ ).

While inefficient pilin assembly in foreign backgrounds may explain changes in phage susceptibility, it is also possible that $S$. maltophilia 280 modifies its surface pili to become unrecognizable 
by some bacteriophages, such as DLP1. Studies of pilus-specific phage in P. aeruginosa have revealed that surface modification of pili via glycosylation can protect the bacteria from phage infection by masking potential binding sites, without creating disadvantageous phenotypes through changes to pilin sequence [59]. While this modification protects P. aeruginosa from infection by most phages, some phages such as DMS3 have developed the ability to bind glycosylated pili and bypass this bacterial defense mechanism [59]. If $S$. maltophilia strain 280 has a modification system for its pili, this modification may mask DLP1's binding site by steric hindrance; however, expressing the 280 pilA gene in a PA01 or D1585 background that lacks this modification system allows DLP1 to recognize a new motif for host recognition, resulting in more efficient infection than expression in 280 (Table 3).

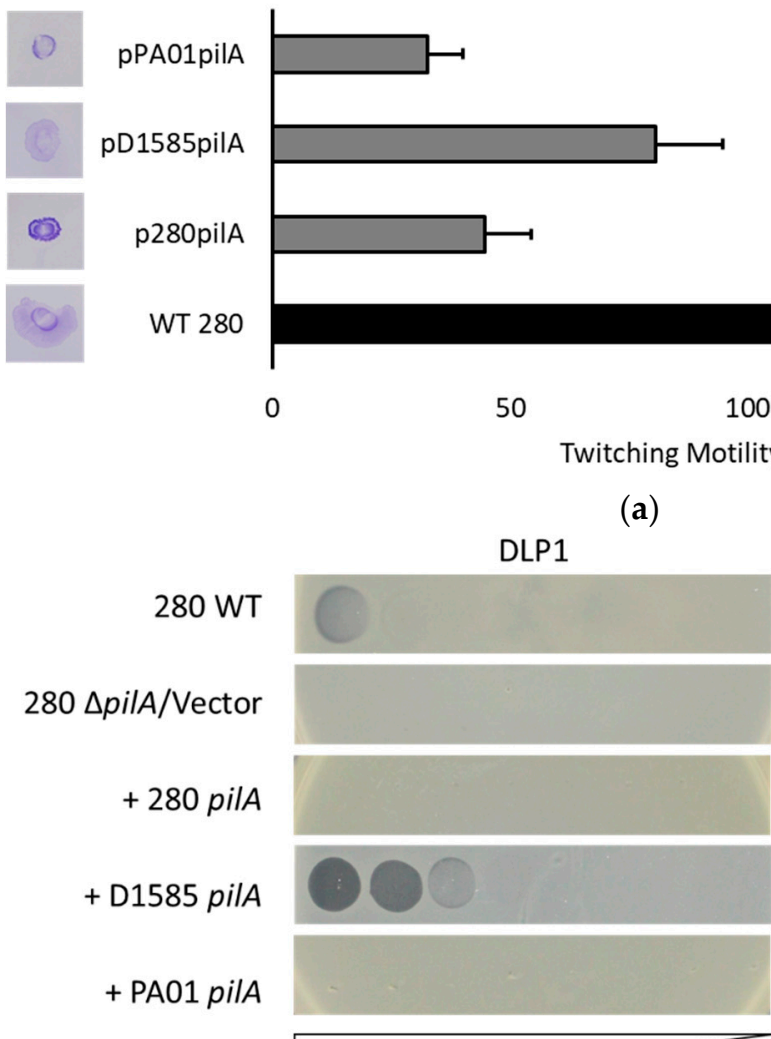

$10^{10}-10^{3}$

(a)
100

150

200

DLP2

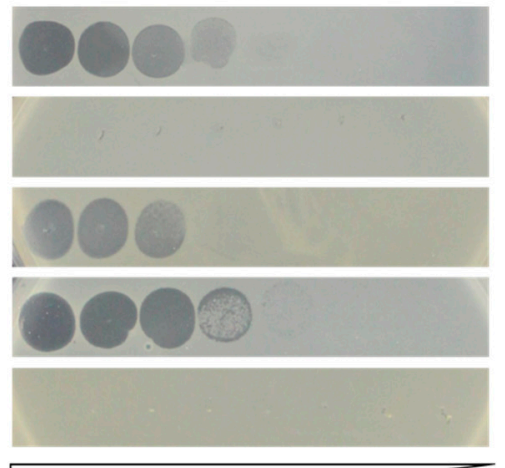

$10^{10}-10^{3}$

(b)

Figure 5. Infection of S. maltophilia 280 expressing varying pilin subunits by DLP1 and DLP2. (a) Twitching motility of the $280 \triangle$ pilA mutant complemented with the PA01, D1585 or endogenous 280 pilA is not restored to wildtype levels and is not correlated with phage susceptibility. Representative twitching zones are shown on the left and the average area of the twitching zones from nine replicates are shown on the right. (b) 280 wildtype (WT) is susceptible to DLP2, while the $280 \triangle$ pilA mutant is resistant. Complementation of $280 \triangle$ pilA with the endogenous pilA gene restores DLP2 infectivity to near wildtype levels, plaquing at $10^{7} \mathrm{PFU} / \mathrm{mL}$. Cross-species complementation with the $S$. maltophilia D1585 pilA gene restores DLP2 infectivity to wildtype levels, plaquing at $10^{5} \mathrm{PFU} / \mathrm{mL}$, and allows partial DLP1 infectivity, showing plaquing at $10^{8} \mathrm{PFU} / \mathrm{mL}$. Cross-genera complementation with the $P$. aeruginosa PA01 pilA gene does not restore phage infection. Images are representative of three biological replicates, each with three technical replicates.

Tail structures play an essential role in host cell recognition and penetration of the bacterial cell wall structure. Contractile tail Myoviridae phages typically possess tail fiber proteins to help stabilize the tail on the cell surface, whereas non-contractile tail Siphoviridae phages do not necessarily possess 
tail fibers [60]. One such fiberless phage is J-1, a temperate siphovirus isolated from an abnormal fermentation with Lactobacillus casei, which was noted for having no tail fibers [61]. Presumably, tail fibers are unimportant where the phage binding site is of limited size. Alternatively, head or tail tube ligands may provide additional attachment stabilization for the phage [62]. In the case of DLP1 and DLP2, initial binding to the type IV pili may obviate the need for tail fibers, as the pilin binding site is restrictively small. Instead, DLP1 and DLP2 binding appears to rely solely upon baseplate attachment to the pilin subunit, and genome ejection putatively only occurs after pilus retraction to the cell surface, making tail fibers unnecessary. Related Siphoviridae phages, all lacking the presence of known or annotated tail fiber genes, and some of which that have been determined to also bind type IV pili, possess similar central tail hub or major baseplate proteins carrying the pfam 13550 Phage-tail_3 domain (Table 4, Supplementary Figure S1 and Table S3). Our bioinformatic analysis suggests phages without encoded tail fibers, and with baseplate proteins possessing the Phage-tail_3 domain closely related to those of phages DLP1 and DLP2, use pili as a primary receptor to gain access to the host cell. Further experimental testing of this hypothesis is currently in progress in our laboratory.

Table 3. Summary of DLP1 and DLP2 phage susceptibility of cross complemented pilA mutants.

\begin{tabular}{|c|c|c|c|}
\hline \multirow[b]{2}{*}{ A. Strain + DLP1 } & \multicolumn{3}{|c|}{ Pilin Complement } \\
\hline & pPA01pilA & pD1585pilA & p280pilA \\
\hline P. aeruginosa PA01 pilA- & $10^{9}$ & $10^{8}$ & $10^{9}$ \\
\hline S. maltophilia D1585spilA & $10^{7}$ & $10^{3}$ & $10^{5}$ \\
\hline S. maltophilia $280 \Delta$ pilA & - & $10^{8}$ & - \\
\hline B. Strain + DLP2 & pPA01pilA & pD1585pilA & p280pilA \\
\hline P. aeruginosa PA01 pilA- & - & $10^{7}$ & $10^{8}$ \\
\hline S. maltophilia D1585apilA & $10^{9}$ & $10^{3}$ & $10^{3}$ \\
\hline S. maltophilia $280 \Delta$ pilA & - & $10^{5}$ & $10^{7}$ \\
\hline
\end{tabular}

Darker shading indicates increased susceptibility to phages: $\square$ no infection, $\square$ clearing at $10^{9}, \square$ plaquing at $10^{9}$, $\square$ clearing at $10^{8}, \square$ plaquing at $10^{7}, \square$ plaquing at $10^{5}, \square$ plaquing at $10^{3}$.

The type IV pilus is a common receptor for many P. aeruginosa specific phages, including PO4 [63], F116 [64], DMS3 [65], MP22 [66], and MPK7 [67]; however this study is the first to identify the type IV pilus as the surface receptor for phages that infect $S$. maltophilia. The type IV pilus is a well characterized virulence factor in many bacteria, including P. aeruginosa and N. gonorrhoeae, involved in surface motility, biofilm formation, and adherence to mammalian cells and surfaces [44]. The results presented identify the type IV pilus as the primary receptor for both DLP1 and DLP2, with implications for phage therapy. Several studies have shown the ability of bacteriophages to increase bacterial virulence through moron genes encoded by the phage; however phages may also provide a selective pressure against bacteria expressing specific virulence factors [16]. Although bacteria may become resistant to phages through modification of phage receptors, when the phage receptor is a virulence factor such as lipopolysaccharide or type IV pili, this mutation provides resistance at the cost of lowered virulence and reduced fitness compared to non-resistant cells [16]. Therapy targeting bacterial virulence factors has been termed an "anti-virulence strategy" [68] and such a strategy using an antibiotic in combination with a phage targeting a $P$. aeruginosa efflux pump responsible for antibiotic resistance has been used successfully to treat a patient's life-threatening aortic infection [15,69]. Therefore, the application of "anti-virulence" phages such as DLP1 and DLP2 may prove to be an effective therapy for clearing S. maltophilia and P. aeruginosa infections, while potentially reducing the virulence of resistant mutants that may arise. 
Table 4. Amino acid sequence comparison of DLP1 and DLP2 phage central tail hub proteins containing the Pfam13550 Phage-tail_3 domain of Siphoviridae phages.

\begin{tabular}{lccc}
\hline \multicolumn{1}{c}{ Bacteriophage } & Accession & $\begin{array}{c}\text { \% Homology to } \\
\text { DLP1 Pfam13550 }\end{array}$ & $\begin{array}{c}\text { \% Homology to } \\
\text { DLP2 Pfam13550 }\end{array}$ \\
\hline Stenotrophomonas phage DLP1 a & AKI28788.1 & - & 98.3 \\
Pseudomonas phage 73 & YP_001293432 & 99.5 & 98.5 \\
Pseudomonas phage vB_PaeS_C1 & AVJ48095 & 98.8 & 99.3 \\
Pseudomonas phage vB_Pae-Kakheti25 & YP_006299890 & 98.5 & 99.1 \\
Pseudomonas phage vB_Pae_PS9N & AIW01689 & 98.4 & 98.4 \\
Stenotrophomonas phage DLP2 a & AKI28730.1 & 98.3 & - \\
Pseudomonas phage vB_PaeS_SCH_Ab26 & YP_009044360 & 97.9 & 97.4 \\
Pseudomonas phage PaMx42 & YP_009205621 & 69.3 & 69.7 \\
Burkholderia phage KL1 & YP_006560777 & 46.8 & 46.8 \\
Xylella phage Sano a,b & AHB12068 & 29.5 & 29.4 \\
Xylella phage Salvo a,b & AHB12243 & 29 & 28.8 \\
\hline
\end{tabular}

${ }^{a}$ Experimentally confirmed as pili-binding phages. ${ }^{b}$ One tail fiber gene annotated, but no tail fiber hits using nucleotide sequence for CD-search against database CDD v3.16-50369 PSSMs with the expected E-value threshold of 0.01 , and composition-based statistics adjustment checked.

Supplementary Materials: Supplementary materials can be found at http:/ /www.mdpi.com/1999-4915/10/6/ 338/s1.

Author Contributions: Conceptualization, J.G.M. and J.J.D.; Methodology, J.G.M., D.L.P. and J.J.D.; Software, J.G.M. and D.L.P. Formal Analysis, J.G.M.; Investigation, J.G.M., D.L.P. and J.J.D; Data Curation, J.G.M. and D.L.P.; Writing-Original Draft Preparation, J.G.M.; Writing-Review and Editing, J.G.M. and J.J.D.; Supervision, J.J.D.; Project Administration, J.J.D.; Funding Acquisition, J.J.D.

Funding: J.J.D. gratefully acknowledges operating grant funding from the Natural Sciences and Engineering Research Council of Canada (NSERC), grant number \# 238414.

Acknowledgments: The authors would like to thank Arlene Oatway from the University of Alberta Department of Biological Sciences Advanced Microscopy Facility for assistance with electron microscopy. The authors thank Shawn Lewenza from the University of Calgary for gifting the PA01 transposon mutant library, as well as the Canadian Burkholderia cepacia complex Research and Referral Repository (CBCCRRR, Vancouver, BC, Canada) and The Provincial Laboratory for Public Health-North (Microbiology), Alberta Health Services, for gifts of the S. maltophilia strains used in this study. J.G.M. was kindly supported by a CGS-M scholarship award from NSERC, and a summer studentship from Alberta Innovates-Health Solutions. D.L.P. was kindly supported by a PGS-D award from NSERC, and a scholarship from Alberta Innovates-Technology Futures.

Conflicts of Interest: The authors declare no conflict of interest. The founding sponsors had no role in the design of the study; in the collection, analyses, or interpretation of data; in the writing of the manuscript, and in the decision to publish the results.

\section{References}

1. O'Neill, J. Tackling Drug-Resistant Infections Globally: Final Report and Recommendations. The Review on Antimicrobial Resistance. Available online: https://amr-review.org/sites/default/files/160518_Final\% 20paper_with\%20cover.pdf (accessed on 7 May 2018).

2. Brooke, J.S. Stenotrophomonas maltophilia: An emerging global opportunistic pathogen. Clin. Microbiol. Rev. 2012, 25, 2-41. [CrossRef] [PubMed]

3. Berg, G.; Martinez, J.L. Friends or foes: Can we make a distinction between beneficial and harmful strains of the Stenotrophomonas maltophilia complex? Front. Microbiol. 2015, 6, 241. [CrossRef] [PubMed]

4. Ryan, R.P.; Monchy, S.; Cardinale, M.; Taghavi, S.; Crossman, L.; Avison, M.B.; Berg, G.; van der Lelie, D.; Dow, J.M. The versatility and adaptation of bacteria from the genus Stenotrophomonas. Nat. Rev. Microbiol. 2009, 7, 514-525. [CrossRef] [PubMed]

5. Pabary, R.; Singh, C.; Morales, S.; Bush, A.; Alshafi, K.; Bilton, D.; Alton, E.W.F.W.; Smithyman, A.; Davies, J.C. Antipseudomonal bacteriophage reduces infective burden and inflammatory response in murine lung. Antimicrob. Agents Chemother. 2016, 60, 744-751. [CrossRef] [PubMed]

6. Pires, D.P.; Vilas Boas, D.; Sillankorva, S.; Azeredo, J. Phage therapy: A step forward in the treatment of Pseudomonas aeruginosa infections. J. Virol. 2015, 89, 7449-7456. [CrossRef] [PubMed] 
7. Pompilio, A.; Pomponio, S.; Crocetta, V.; Gherardi, G.; Verginelli, F.; Fiscarelli, E.; Dicuonzo, G.; Savini, V.; D'Antonio, D.; Di Bonaventura, G. Phenotypic and genotypic characterization of Stenotrophomonas maltophilia isolates from patients with cystic fibrosis: Genome diversity, biofilm formation, and virulence. BMC Microbiol. 2011, 11, 159. [CrossRef] [PubMed]

8. McVay, C.S.; Velásquez, M.; Fralick, J.A. Phage therapy of Pseudomonas aeruginosa in a mouse burn wound model. Antimicrob. Agents Chemother. 2007, 51, 1934-1938. [CrossRef] [PubMed]

9. Seed, K.D.; Dennis, J.J. Experimental bacteriophage therapy increases survival of Galleria mellonella larvae infected with clinically relevant strains of the Burkholderia cepacia complex. Antimicrob. Agents Chemother. 2009, 53, 2205-2208. [CrossRef] [PubMed]

10. Semler, D.D.; Goudie, A.D.; Finlay, W.H.; Dennis, J.J. Aerosol phage therapy efficacy in Burkholderia cepacia complex respiratory infections. Antimicrob. Agents Chemother. 2014, 58, 4005-4013. [CrossRef] [PubMed]

11. Merabishvili, M.; Pirnay, J.P.; Verbeken, G.; Chanishvili, N.; Tediashvili, M.; Lashkhi, N.; Glonti, T.; Krylov, V.; Mast, J.; Van Parys, L.; et al. Quality-controlled small-scale production of a well-defined bacteriophage cocktail for use in human clinical trials. PLoS ONE 2009, 4, e4944. [CrossRef] [PubMed]

12. Wright, A.; Hawkins, C.H.; Änggård, E.E.; Harper, D.R. A controlled clinical trial of a therapeutic bacteriophage preparation in chronic otitis due to antibiotic-resistant Pseudomonas aeruginosa; A preliminary report of efficacy. Clin. Otolaryngol. 2009, 34, 349-357. [CrossRef] [PubMed]

13. Vandenheuvel, D.; Lavigne, R.; Brüssow, H. Bacteriophage therapy: Advances in formulation strategies and human clinical trials. Annu. Rev. Virol. 2015, 2, 599-618. [CrossRef] [PubMed]

14. Schooley, R.T.; Biswas, B.; Gill, J.J.; Hernandez-Morales, A.; Lancaster, J.; Lessor, L.; Barr, J.J.; Reed, S.L.; Rohwer, F.; Benler, S.; et al. Development and use of personalized bacteriophage-based therapeutic cocktails to treat a patient with a disseminated resistant Acinetobacter baumannii infection. Antimicrob. Agents Chemother. 2017, 61, e00954-17. [CrossRef] [PubMed]

15. Chan, B.K.; Turner, P.E.; Kim, S.; Mojibian, H.R.; Elefteriades, J.A.; Narayan, D. Phage treatment of an aortic graft infected with Pseudomonas aeruginosa. Evol. Med. Public Health 2018, 2018, 60-66. [CrossRef] [PubMed]

16. Leon, M.; Bastias, R. Virulence reduction in bacteriophage resistant bacteria. Front. Microbiol. 2015, 6, 343. [CrossRef] [PubMed]

17. Peters, D.L.; Lynch, K.H.; Stothard, P.; Dennis, J.J. The isolation and characterization of two Stenotrophomonas maltophilia bacteriophages capable of cross-taxonomic order infectivity. BMC Genom. 2015, 16, 664. [CrossRef] [PubMed]

18. Abedon, S.T.; Kuhl, S.J.; Blasdel, B.G.; Kutter, E.M. Phage treatment of human infections. Bacteriophage 2011, 1, 66-85. [CrossRef] [PubMed]

19. Peters, D.L.; Stothard, P.; Dennis, J.J. The isolation and characterization of Stenotrophomonas maltophilia T4-like bacteriophage DLP6. PLoS ONE 2017, 12, e0173341. [CrossRef] [PubMed]

20. Lewenza, S.; Falsafi, R.K.; Winsor, G.; Gooderham, W.J.; Mcphee, J.B.; Brinkman, F.S.L.; Hancock, R.E.W. Construction of a mini-Tn5-luxCDABE mutant library in Pseudomonas aeruginosa PAO1: A tool for identifying differentially regulated genes. Genome Res. 2005, 15, 583-589. [CrossRef] [PubMed]

21. Jacobs, M.A.; Alwood, A.; Thaipisuttikul, I.; Spencer, D.; Haugen, E.; Ernst, S.; Will, O.; Kaul, R.; Raymond, C.; Levy, R.; et al. Comprehensive transposon mutant library of Pseudomonas aeruginosa. Proc. Natl. Acad. Sci. USA 2003, 100, 14339-14344. [CrossRef] [PubMed]

22. Held, K.; Ramage, E.; Jacobs, M.; Gallagher, L.; Manoil, C. Sequence-verified two-allele transposon mutant library for Pseudomonas aeruginosa PAO1. J. Bacteriol. 2012, 194, 6387-6389. [CrossRef] [PubMed]

23. Krylov, V.N.; Zhazykov, I. Pseudomonas bacteriophage phiKZ—Possible model for studying the genetic control of morphogenesis. Genetika 1978, 14, 678-685. [PubMed]

24. Kropinski, A.M.; Mazzocco, A.; Waddell, T.E.; Lingohr, E.; Johnson, R.P. Enumeration of bacteriophages by double agar overlay plaque assay. In Bacteriophages: Methods and Protocols, Volume 1: Isolation, Charcterization, and Interactions; Clokie, M.R.J., Kropinski, A.M., Eds.; Humana Press: New Delhi, India, 2009; pp. 69-76.

25. Holloway, B.W. Genetic Recombination in Pseudomonas aeruginosa. J. Gen. Microbiol. 1955, 13, 572-581. [CrossRef] [PubMed]

26. Simon, R.; Priefer, U.; Puhler, A. A broad host range mobilization system for in vivo genetic engineering: Transposon mutagenesis in gram negative bacteria. Nat. Biotechnol. 1983, 1, 784-791. [CrossRef]

27. Hanahan, D.; Jessee, J.; Bloom, F.R. Plasmid transformation of Escherichia coli and other bacteria. Methods Enzymol. 1991, 204, 63-113. [PubMed] 
28. Mesyanzhinov, V.V.; Robben, J.; Grymonprez, B.; Kostyuchenko, V.A.; Bourkaltseva, M.V.; Sykilinda, N.N.; Krylov, V.N.; Volckaert, G. The genome of bacteriophage phiKZ of Pseudomonas aeruginosa. J. Mol. Biol. 2002, 317, 1-19. [CrossRef] [PubMed]

29. Kovach, M.E.; Phillips, R.W.; Elzer, P.H.; Roop, R.M.; Peterson, K.M. pBBR1MCS: A broad-host-range cloning vector. Biotechniques 1994, 16, 800-802. [PubMed]

30. West, S.E.H.; Schweizer, H.P.; Dall, C.; Sample, A.K.; Runyen-Janecky, L.J. Construction of improved Escherichia-Pseudomonas shuttle vectors derived from pUC18/19 and sequence of the region required for their replication in Pseudomonas aeruginosa. Gene 1994, 128, 81-86. [CrossRef]

31. Hoang, T.T.; Karkhoff-Schweizer, R.R.; Kutchma, A.J.; Schweizer, H.P. A broad-host-range Flp-FRT recombination system for site-specific excision of chromosomally-located DNA sequences: Application for isolation of unmarked Pseudomonas aeruginosa mutants. Gene 1998, 212, 77-86. [CrossRef]

32. Kearse, M.; Moir, R.; Wilson, A.; Stones-Havas, S.; Cheung, M.; Sturrock, S.; Buxton, S.; Cooper, A.; Markowitz, S.; Duran, C.; et al. Geneious basic: An integrated and extendable desktop software platform for the organization and analysis of sequence data. Bioinform. Appl. Note 2012, 19, 1647-1649. [CrossRef] [PubMed]

33. Edgar, R.C. MUSCLE: Multiple sequence alignment with high accuracy and high throughput. Nucleic Acids Res. 2004, 32, 1792-1797. [CrossRef] [PubMed]

34. Chojnacki, S.; Cowley, A.; Lee, J.; Foix, A.; Lopez, R. Programmatic access to bioinformatics tools from EMBL-EBI update: 2017. Nucleic Acids Res. 2017, 45, W550-W553. [CrossRef] [PubMed]

35. Hmelo, L.R.; Borlee, B.R.; Almblad, H.; Love, M.E.; Randall, T.E.; Tseng, B.S.; Lin, C.; Irie, Y.; Storek, K.M.; Yang, J.J.; et al. Precision-engineering the Pseudomonas aeruginosa genome with two-step allelic exchange. Nat. Protoc. 2015, 10, 1820-1841. [CrossRef] [PubMed]

36. Heckman, K.L.; Pease, L.R. Gene splicing and mutagenesis by PCR-driven overlap extension. Nat. Protoc. 2007, 2, 924-932. [CrossRef] [PubMed]

37. Poole, K.; Heinrichs, D.E.; Neshat, S. Cloning and sequence analysis of an EnvCD homologue in Pseudomonas aeruginosa: Regulation by iron and possible involvement in the secretion of the siderophore pyoverdine. Mol. Microbiol. 1993, 10, 529-544. [CrossRef] [PubMed]

38. Choi, K.H.; Kumar, A.; Schweizer, H.P. A 10-min method for preparation of highly electrocompetent Pseudomonas aeruginosa cells: Application for DNA fragment transfer between chromosomes and plasmid transformation. J. Microbiol. Methods 2006, 64, 391-397. [CrossRef] [PubMed]

39. Ye, X.; Dong, H.; Huang, Y.P. Highly efficient transformation of Stenotrophomonas maltophilia S21, an environmental isolate from soil, by electroporation. J. Microbiol. Methods 2014, 107, 92-97. [CrossRef] [PubMed]

40. Turnbull, L.; Whitchurch, C.B. Motility assay: Twitching motility. In Pseudomonas Methods and Protocols; Filloux, A., Ramos, J.-L., Eds.; Humana Press: New York, NY, USA, 2014; Volume 1149, pp. 73-86. ISBN 978-1-4939-0472-3.

41. Pompilio, A.; Crocetta, V.; Ghosh, D.; Chakrabarti, M.; Gherardi, G.; Vitali, L.A.; Fiscarelli, E.; Di Bonaventura, G. Stenotrophomonas maltophilia phenotypic and genotypic diversity during a 10-year colonization in the lungs of a cystic fibrosis patient. Front. Microbiol. 2016, 7, 1551. [CrossRef] [PubMed]

42. Schneider, C.A.; Rasband, W.S.; Eliceiri, K.W. NIH Image to ImageJ: 25 years of image analysis. Nat. Methods 2012, 9, 671-675. [CrossRef] [PubMed]

43. Marchler-Bauer, A.; Bo, Y.; Han, L.; He, J.; Lanczycki, C.J.; Lu, S.; Chitsaz, F.; Derbyshire, M.K.; Geer, R.C.; Gonzales, N.R.; et al. CDD/SPARCLE: Functional classification of proteins via subfamily domain architectures. Nucleic Acids Res. 2017, 45, D200-D203. [CrossRef] [PubMed]

44. Burrows, L.L. Pseudomonas aeruginosa twitching motility: Type IV pili in action. Annu. Rev. Microbiol. 2012, 66, 493-520. [CrossRef] [PubMed]

45. Whitchurch, C.B.; Mattick, J.S. Characterization of a gene, pilU, required for twitching motility but not phage sensitivity in Pseudomonas aeruginosa. Mol. Microbiol. 1994, 13, 1079-1091. [CrossRef] [PubMed]

46. Burrows, L.L. Weapons of mass retraction. Mol. Microbiol. 2005, 57, 878-888. [CrossRef] [PubMed]

47. Nguyen, Y.; Sugiman-Marangos, S.; Harvey, H.; Bell, S.D.; Charlton, C.L.; Junop, M.S.; Burrows, L.L. Pseudomonas aeruginosa minor pilins prime type IVa pilus assembly and promote surface display of the PilY1 adhesin. J. Biol. Chem. 2015, 290, 601-611. [CrossRef] [PubMed] 
48. Kus, J.V.; Tullis, E.; Cvitkovitch, D.G.; Burrows, L.L. Significant differences in type IV pilin allele distribution among Pseudomonas aeruginosa isolates from cystic fibrosis (CF) versus non-CF patients. Microbiology 2004, 150, 1315-1326. [CrossRef] [PubMed]

49. Giltner, C.L.; Rana, N.; Lunardo, M.N.; Hussain, A.Q.; Burrows, L.L. Evolutionary and functional diversity of the Pseudomonas type IVa pilin island. Environ. Microbiol. 2011, 13, 250-264. [CrossRef] [PubMed]

50. Elleman, T.C.; Hoyne, P.A.; Stewart, D.J.; Mckern, N.M.; Peterson, J.E. Expression of pili from Bacteroides nodosus in Pseudomonas aeruginosa. J. Bacteriol. 1986, 168, 574-580. [CrossRef] [PubMed]

51. Beard, M.K.M.; Mattick, J.S.; Moore, L.J.; Mott, M.R.; Marrs, C.F.; Egerton, J.R. Morphogenetic expression of Moraxella bovis fimbriae (pili) in Pseudomonas aeruginosa. J. Bacteriol. 1990, 172, 2601-2607. [CrossRef] [PubMed]

52. Hoyne, P.A.; Haas, R.; Meyer, T.F.; Davies, J.K.; Elleman, T.C. Production of Neisseria gonorrhoeae pili (fimbriae) in Pseudomonas aeruginosa. J. Bacteriol. 1992, 174, 7321-7327. [CrossRef] [PubMed]

53. Sauvonnet, N.; Gounon, P.; Pugsley, A.P. PpdD type IV pilin of Escherichia coli K-12 can be assembled into pili in Pseudomonas aeruginosa. J. Bacteriol. 2000, 182, 848-854. [CrossRef] [PubMed]

54. Aas, F.E.; Wolfgang, M.; Frye, S.; Dunham, S.; Løvold, C.; Koomey, M. Competence for natural transformation in Neisseria gonorrhoeae: Components of DNA binding and uptake linked to type IV pilus expression. Mol. Microbiol. 2002, 46, 749-760. [CrossRef] [PubMed]

55. Roine, E.; Raineri, D.M.; Romantschuk, M.; Wilson, M.; Nunn, D.N. Characterization of type IV pilus genes in Pseudomonas syringae pv. tomato DC3000. Mol. Plant-Microbe Interact. 1998, 11, 1048-1056. [CrossRef] [PubMed]

56. Watson, A.A.; Mattick, J.S.; Aim, R.A. Functional expression of heterologous type 4 fimbriae in Pseudomonas aeruginosa. Gene 1996, 175, 143-150. [CrossRef]

57. Winther-Larsen, H.C.; Wolfgang, M.C.; Van Putten, J.P.M.; Roos, N.; Aas, F.E.; Egge-Jacobsen, W.M.; Maier, B.; Koomey, M. Pseudomonas aeruginosa type IV pilus expression in Neisseria gonorrhoeae: Effects of pilin subunit composition on function and organelle dynamics. J. Bacteriol. 2007, 189, 6676-6685. [CrossRef] [PubMed]

58. Haley, C.L.; Kruczek, C.; Qaisar, U.; Colmer-Hamood, J.A.; Hamood, A.N. Mucin inhibits Pseudomonas aeruginosa biofilm formation by significantly enhancing twitching motility. Can. J. Microbiol. 2014, 60, 155-166. [CrossRef] [PubMed]

59. Harvey, H.; Bondy-Denomy, J.; Marquis, H.; Sztanko, K.M.; Davidson, A.R.; Burrows, L.L. Pseudomonas aeruginosa defends against phages through type IV pilus glycosylation. Nat. Microbiol. 2018, 3, 47-52. [CrossRef] [PubMed]

60. Davidson, A.R.; Cardarelli, L.; Pell, L.G.; Radford, D.R.; Maxwell, K.L. Long Noncontractile Tail Machines of Bacteriophages. In Viral Molecular Machines; Rossman, M.G., Rao, V.B., Eds.; Springer: Boston, MA, USA, 2012; pp. 115-142.

61. Watanabe, K.; Ishibashi, K.; Nakashima, Y.; Sakurai, T. A phage-resistant mutant of Lactobacillus casei which permits phage adsorption but not genome injection. J. Gen. Virol. 1984, 65, 981-986. [CrossRef] [PubMed]

62. Guttman, B.; Raya, R.; Kutter, E.M. Basic Phage Biology. In Bacteriophages: Biology and Applications; Kutter, E., Sulakvelidze, A., Eds.; CRC Press: Boca Raton, FL, USA, 2005; ISBN 0849313368.

63. Bradley, D.E. A pilus-dependent Pseudomonas aeruginosa bacteriophage with a long noncontractile tail. Virology 1973, 51, 489-492. [CrossRef]

64. Pemberton, J.M. F116: A DNA bacteriophage specific for the pili of Pseudomonas aeruginosa strain PAO. Virology 1973, 55, 558-560. [CrossRef]

65. Budzik, J.M.; Rosche, W.A.; Rietsch, A.; O'toole, G.A. Isolation and characterization of a generalized transducing phage for Pseudomonas aeruginosa strains PAO1 and PA14. J. Bacteriol. 2004, 186, 3270-3273. [CrossRef] [PubMed]

66. Heo, Y.-J.; Chung, I.-Y.; Choi, K.B.; Lau, G.W.; Cho, Y.-H. Genome sequence comparison and superinfection between two related Pseudomonas aeruginosa phages, D3112 and MP22. Microbiology 2007, 153, 2885-2895. [CrossRef] [PubMed]

67. Bae, H.-W.; Cho, Y.-H. Complete genome sequence of Pseudomonas aeruginosa podophage MPK7, which requires type IV pili for infection. Genome Announc. 2013, 1, e00744-13. [CrossRef] [PubMed] 
68. Rasko, D.A.; Sperandio, V. Anti-virulence strategies to combat bacteria-mediated disease. Nat. Rev. 2010, 9, 117-128. [CrossRef] [PubMed]

69. Chan, B.K.; Sistrom, M.; Wertz, J.E.; Kortright, K.E.; Narayan, D.; Turner, P.E. Phage selection restores antibiotic sensitivity in MDR Pseudomonas aeruginosa. Sci. Rep. 2016, 6, 26717. [CrossRef] [PubMed]

(C) 2018 by the authors. Licensee MDPI, Basel, Switzerland. This article is an open access article distributed under the terms and conditions of the Creative Commons Attribution (CC BY) license (http://creativecommons.org/licenses/by/4.0/). 